ACTA THERIOLOGICA

Vol. 28, 16: 243-258, 1983

\title{
Habitat, Density and Spatial Structure of the Forest Roe Deer Population ${ }^{1}$
}

\author{
Bogusław FRUZINSKI, Lesław ŁABUDZKI \& Marian WLAZEŁKO
}

Fruziński B., Łabudzki L. \& Wlazelko M., 1982: Habitat, density and spatial structure of the forest roe deer population. Acta theriol., 28, 16: 243-258 [With 7 Tables \& 1 Fig.]

During the study period $(1973-1980)$ variations were found in population density from 20.8 individuals per 100 ha to $10.4 / 100$ ha. The most important cause of variations in numbers consisted in winter weather conditions. The roe deer Capreolus capreolus (Linnaeus, 1758) preferred the parts of tree stands in which the coniferous species Pinus silvestris predominated (average 16.1 individuals per 100 ha), to tree stands in which Quercus sessilis predominated (14.1 individuals $/ 100$ ha). Maximum population density was found in the older plantations (21.7 individuals) and thickets (20.9 individuals). The average size of the territory of bucks, depending on the calculation method used, was: 9 ha for the minimum polygon, 10.3 for the convex polygon, and 52.3 ha for the elliptic area of probable activity. Average size of does' home ranges was respectively: 12.2 ha, 15.2 ha and 77 ha. $84.2 \%$ of all marked bucks were observed at a distance of up to $1 \mathrm{~km}$ from the capture site, $47 \%$ of these within a radius of $0.5 \mathrm{~km}$. The corresponding figures for does were $54 \%$ and $33.3 \%$. Migrations to the furthest distances (2.3 km for bucks and $5.2 \mathrm{~km}$ for does) were undertaken by the youngest individuals, caught and marked as fawns.

[Dept. of Game Management, Academy of Agriculture, Wojska Polskiego 71d, 60-625 Poznań, Poland].

\section{INTRODUCTION}

The roe deer is a species eurybiotic to a very great degree. It currently occurs in different types of forest habitats, in typically cultivated landscapes and also in extensive open fields, or large stretches of meadows (Pielowski, 1970). Population density is most often uneven, depending on the character of the habitat and also on geographical situation. Although a very numerous and also widespread species, at the same time it creates considerable difficulties as to method in ecological studies. This applies primarily to a forest habitat, in which roe deer take advantage of any form of shelter (undergrowth, herb layer vegetation) thus making opportunities for direct observation very limited.

The studies were aimed at describing the density and spatial structure of a roe deer population in wooded land. Examination was made

${ }^{1}$ Badania prowadzone $w$ ramach problemu MR.II,15 koordynowanego przez Instytut Ekologii PAN. 
of the relation between density and the character of the biotope and age of the tree stand. An attempt was made at defining the size of the territory of males and home range of females, and also the extent of local movements by individuals in the population.

\section{STUDY AREA}

The studies were carried out in the "Zielonka" Experimental Game Research Centre of the Poznan Academy of Agriculture, which includes a fairly dense stretch of wooded land 7,944 ha in extent known as the "Zielonka Forest", situated about $30 \mathrm{~km}$ in a $\mathrm{N}-\mathrm{E}$ direction from Poznań, in the Wielkopolsko-Kujawy Lowland Region, which is a slightly undulating plain formed during the second Frankfurt glaciation period. The frontal moraine raised area and several narrow glacial valleys with lakes contribute to the physiographical variety of the area.

The surface of the study areas is formed of leached type soils consisting of loose sand and slightly clayey glacial accumulation. These soils have only faintly marked morphological characteristics and determine the direction of the development of plant successions. Only a small part of the area is covered by fen type soils - peat, muds and boggy soils (Mucha \& Margowski, 1957).

The tree stands of the Centre are situated in an area in which the mean annual precipitation is the lowest in Poland $(508 \mathrm{~mm})$. Average annual temperature is $+8.6^{\circ} \mathrm{C}$. The growing period with temperatures above $+5^{\circ} \mathrm{C}$ lasts about 220 days. The weather conditions in summer are formed by the continental climate, but in winter by the oceanic climate, which moderates extreme temperatures. There is no marked harmful factory air pollution, as is shown by the state of health of tree stands.

Descriptions of the succession sequence of the flora points to deterioration in the biotope as the level of ground water falls. Oak woods thus change into mixed coniferous woods, and further deterioration in soil conditions will lead to formation of a fresh coniferous forest biotope. The predominating biotopes are mixed fresh coniferous forest and fresh coniferous forest.

The tree stands of the Centre are situated in the spruce-less belt, beyond the natural range of firs, within the limits of the scattered range of beech. The species forming the tree stands are pine (Pinus silvestris) and oak (Quercus sessilis). Pine woods are in the decided majority and occupy $85.2 \%$ of the total wooded area. The majority of pine woods consists almost solely of pine, with a slight proportion of oak and single specimens of birch, spruce, beech and larch. Mixed oak and pine stands also occur, and only occasionally unmixed oak woods (about $10 \%$ of the area) and alder. Several years ago many species of trees and bushes not indigenous to the area were introduced, but they are not of a wood- or biotope-forming character, with the exception of Padus racemosa, which in places of its numerous occurrence forms shady brushwood over stretches several hectares in extent (Nowaczyk, 1964).

The complete clearing method is used for the treestands there, although in a small percentage of the deciduous forests focus clearing is used. Both the species composition of the treestands and thle way in which they are utilized create favourable conditions for development of ground vegetation, which determines the natural food resources for herbivores. There are particularly good food and 
shelter conditions in the relatively large area of plantations and thickets (Table 1). An additional habitat advantage in this respect is the higher than average proportion of surface ecotones in the experimental woods of the Academy of Agriculture (these woods form about $30 \%$ of the total area of the Centre), due to the considerable number of experimental plots in different sectors (Nowaczyk, 1964).

The percentage of forest-field boundaries is $70.2 \%$. The structure of agricultural

Table 1

Distribution of forest and age classes of stands at Zielonka.

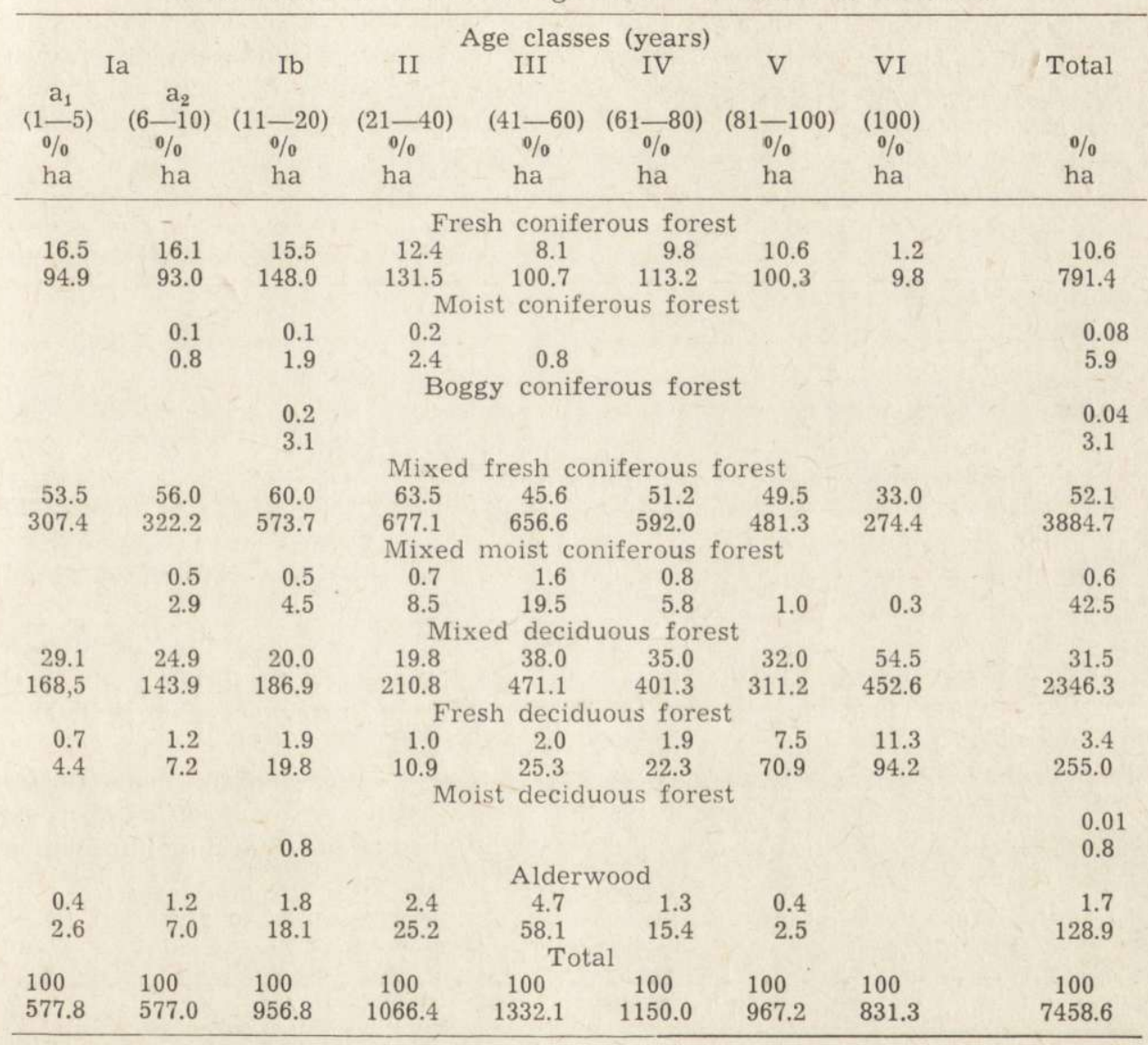

crops in fields adjoining treestands is determined by the low fertility of these soils (classes V and VI). It must however be emphasized that there is rational and intensive cultivation of soils near tree stands.

\section{STUDY METHODS}

There are considerable difficulties of a technical and methodical nature in establishing the numbers or population density of roe deer in wooded areas. On this account a fairly variable study technique was used. A map was prepared 
of tree stands and 19 sample areas were marked out, distributed evenly over the whole area (although taking into consideration the situation of enclaves of fields and meadows). The total area over which drives were carried out was 767.71 ha, which constituted almost exactly $10 \%$ of the whole of the wooded land of the Centre. The extent of one drive varied from 15 to 68 ha. These differences were due to the principles of the chosen method, since endeavour was made to mark out sample areas as uniform as possible, in which one age class of treestand only was represented (e.g. plantation, thicket, pole-sized stand) or one or two biotopic types of forest similar to each other. This made it possible to examine the density of the roe deer there depending on the age structure of the tree stand and the biotopic type of the wood. Two basic types of biotope were distinguished, namely pine forest (fresh coniferous, mixed moist coniferous) with decided predominance of pine in species composition of the tree stands, and mixed deciduous forest, with a considerable proportion of oak and slight admixture of pine. It proved possible to determine biotope differentiation in 19 marked out areas (which most often covered whole forest sectors, sometimes part of them or uniform parts of treestands in $100 \%$ of cases). Fresh and mixed moist coniferous forests covered $58 \%$ of the sample areas, and mixed deciduous forests $-42 \%$.

The distribution of age classes over the sample areas was less even. The development stages of the tree stand were represented there as follows: young plantations - about $12 \%$, thickets $-23 \%$, pole-sized stands $-25 \%$ and older tree stands $40 \%$, which approximately corresponds to their representation over the whole wooded area.

Complete age range was obtained in 13 areas, while in 6 it was impossible to avoid partial mixing of two or even 3 age classes. In some areas where there were 2 different age classes of treestand, additional observers were stationed on the boundary between marked-out areas.

About 80 persons (observers and beaters) took part each time in the drives, using the method for carrying out drives after Pucek et al. (1975). From 1973 -1980 drives covered all 19 experimental plots, took place every year during the spring period from 16-23 March (133 trials).

In order to determine the size of the territories of males and the home ranges of females, local movements and the use made by roe deer of different parts of the biotope as feeding grounds, the following ways of obtaining information were employed:

- direct observations of individuals from permanent raised observation posts,

- transecting line on permanent observation routes,

- data from experimental drives,

- observation record cards during individual hunting, on which the time and place of observations of each marked individual encountered were entered.

On a selected part of the hunting area ( 730 ha wooded land) as from 1973 organized captures of roe deer were made, using nets. Each individual caught was marked by means of a leather collar carrying an enamel plate, fastened on the animal's neck. Strandgaard (1972) successfully used this method in his studies on the roe deer. In place of the enamel number plate leather ones were also used on which numbers had been affixed using reflecting plastic but without much success, since they were not resistant to wear or the effect of other external conditions. Captures were made in February and March from 1973-1977.

In all 84 roe deer: 39 males and 45 females were caught and marked. All 
observations of marked individuals were entered on an accurate map of the area, scale $1: 1000$.

The size of bucks' territories and does' home ranges was calculated comparatively by means of two methods, i.e. the minimum polygon and convex polygon, taken after Stickel (1954) and Southwood (1966), in accordance with the equation:

$$
A=\frac{1}{2} \sum_{i=1}^{n}\left(x_{i} y_{i+1}-x_{i}+1 y_{i}\right)
$$

where $A$ - size of territory or home range, $n$ - number of observations, $i-$ successive observations, $x$ and $y$ - co-ordinates of the observation point.

The size of coordinates was given in hectometres. The above calculations were made solely for individuals, the localization of which had been determined at least 5 times (min. 5 - max. 15 observations), those in the case of bucks applying only to the period of their territorial behaviour (April - Sept.), whereas the period for does covered the whole year. The results obtained were compared with the method proposed by Jenrich \& Turner (1969) for calculating the elliptic area of probable activity.

The use made by roe deer of certain parts of a tree stand as feeding places was defined by means of direct observation of feeding individuals in the early morning and evening hours, until dusk fell. Three permanent routes (transecting lines) were set up, the total length of which was $12 \mathrm{~km}$. The proportion of young plantations, timber stands and wood-field boundaries was equal. As from the beginning of March 1976 to the end of February 1977, 81 regular inspections (every 4-5 days, morning and evening) were made of the routes in question. The combined observation time was about 320 hours, during which 938 roe deer were observed.

Analogical observations were made from March to the end of May 1977 (302 observed roe deer) and from October to the end of December $1977-273$ roe deer observed.

\section{RESULTS}

\subsection{Population Density}

Over the course of 8 years fairly distinct variation was observed in the spring population density of roe deer, from 20.8 individuals per 100 ha of wooded area in 1975 to 10.4 individuals in the spring of 1979 (Fig. 1). The cause of the greatest decrease in density undoubtedly consists in severe and snowy winters bringing about considerable natural mortality. Mortality, usually low, of less than $10 \%$ of the autumn head of roe deer (Fruziński \& Łabudzki, 1963), increases under conditions of long-lasting snow cover.

As from 1975 to the spring of 1979 there was a distinct tendency to decrease in the spring population density. During this period maximum decrease in density was observed, both as the effect of the late winter of 1976/77, and the long-lasting snowfall in March (by 4.6 individuals/ 


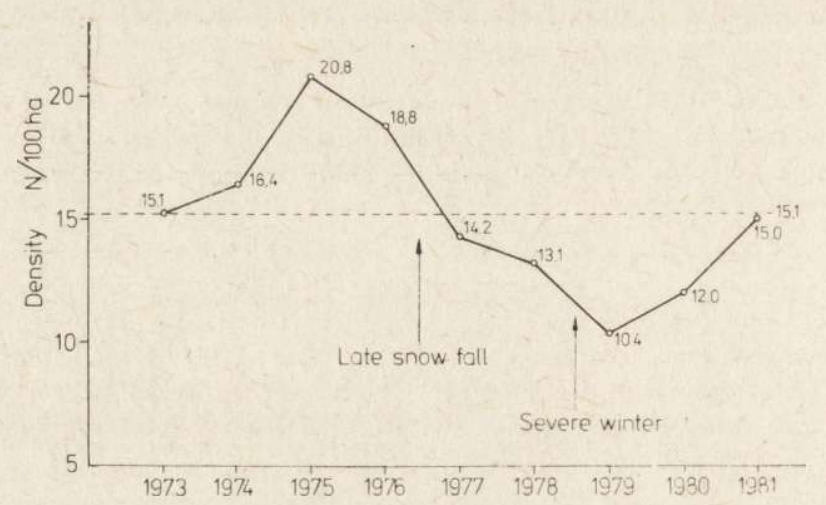

Fig. 1. The density of the roe deer population at Zielonka in 1973-1981.

$100 \mathrm{ha}$ ) and also the exceptionally severe and snowy winter of $1978 / 79$ (by 2.7 individuals/100 ha) (Fig. 1). As from the spring of 1980 a renewed increase in population density was observed, which in 1981 reached the value attained 8 years previously, at the same time being the average population density in the given period (Fig. 1).

Coniferous forests proved to be more attractive to roe deer than deciduous woods, as is shown by differences in population density (Table 2). On an average these differences are statistically significant for an 8-year period, as shown by the analysis of variance made $(P<0.05)$ : the value of the lowest significant difference $(N I R$, expressed by the quotient of estimated error and degrees of freedom for error) was 1.74 . The most highly statistically significant differences in the spring population density in coniferous and deciduous forests was thus observed during the period 1973-1976, with a simultaneous fairly high total population density (Table 2). Differences in density not statistically

Table 2

Roe deer population density in two types of habitats.

\begin{tabular}{ccccc}
\hline Year & $\begin{array}{c}\text { Coniferous } \\
\text { forest }\end{array}$ & $\begin{array}{c}\text { Decidous } \\
\text { forest }\end{array}$ & Difference & $\begin{array}{c}\text { Total on the } \\
\text { study area }\end{array}$ \\
\hline 1973 & 16.9 & 13.6 & $3.3^{1}$ & 15.2 \\
1974 & 18.8 & 14.0 & $4.8^{1}$ & 16.4 \\
1975 & 22.7 & 18.9 & $3.8^{1}$ & 20.8 \\
1976 & 19.8 & 17.9 & $2.1^{1}$ & 18.8 \\
1977 & 14.7 & 13.7 & 1.0 & 14.2 \\
1978 & 13.6 & 12.6 & 1.0 & 13.1 \\
1979 & 11.1 & 9.7 & 1.4 & 10.4 \\
1980 & 13.1 & 10.9 & $2.2^{1}$ & 12.0 \\
Avg. & 16.1 & 14.1 & $2.0^{1}$ & 15.1 \\
\hline
\end{tabular}

1 The differences are statistically significant, NIR (smallest essential difference $)=1.74$ 
significant occurred from 1977-1979, during the phase of population decrease due to severe winters.

In respect of age differentiation it was the older plantations and thickets which proved most attractive to roe deer during the study period, average density being respectively: 21.7 and 20.9 individuals/ 100 ha. Far lower density was found in the pole-sized stands (15.6 inaividual/100 ha), and lowest - 9.4 individual $/ 100$ ha - in timber stands (Table 3). Population density in age classes of tree stand exhibits statistically significant differences $(P<0.05)$. On an average over the study period it was only differences in population density in plantations and thickets which were not significant, but were highly significant between the youngest age classes and between timber stands and pole-sized stands $(N I R=5.44)$. In some years differences in density, even in the same age classes of tree stands, are frequently considerable (Table 3).

Table 3

Population density in different age classes of stands.

\begin{tabular}{ccccc}
\hline Year & $\begin{array}{c}\text { Young } \\
\text { plantations }\end{array}$ & Thickets & $\begin{array}{c}\text { Pole-sized } \\
\text { stands }\end{array}$ & $\begin{array}{c}\text { Timber } \\
\text { stands }\end{array}$ \\
1974 & 34.1 & 19.0 & 17.6 & 9.3 \\
1975 & 32.0 & 26.4 & 23.8 & 12.7 \\
1976 & 13.4 & 30.7 & 15.5 & 15.4 \\
1977 & 16.5 & 20.1 & 14.5 & 10.0 \\
1978 & 13.8 & 18.2 & 13.4 & 9.7 \\
1979 & 18.6 & 16.2 & 11.9 & 3.6 \\
1980 & 23.7 & 16.2 & 12.9 & 5.3 \\
Avg. & 21.7 & 20.9 & 15.61 & $9.4^{1}$ \\
\hline
\end{tabular}

1 The differences are statistically significant, NIR (smallest essential difference) $=5.44$

The differences were analyzed in this connection only in relation to the average values for the whole study period (Table 3 ), assuming that with necessarily small study areas, weather conditions at least might affect results in different years. The possibility of this kind of error was to a great extent eliminated by the calculated (from the study period) sample area, which was respectively: 677 ha for plantations, 1253 ha for thickets, 1341 ha for pole-sized stands and as much as 2100 ha for timber stands.

\subsection{Utilization of Different Types of Daytime Feeding Places}

The use made of different parts of the forest biotope as feeding places reveals considerable seasonal variations. During the period March-July the roe deer fairly evenly utilize different types of feeding places, frequently also moving into fields near tree stands where they fed on winter cereals (in early spring) and serradilla and fodder lupin 
(in summer). During the period September-December there was a distinct and systematic decrease in intensity of feeding on field crops, and it was not until towards the end of the winter period that this increased.

In summer and autumn (July-September) roe deer most often fed on forest plantations and in tree stands of the older age classes (Table 4). The degree of attractiveness of older oak tree stands clearly

Table 4

Distribution of the number and percentage of roe deer observed on the different types of the feeding areas.

\begin{tabular}{|c|c|c|c|c|c|c|}
\hline \multirow[b]{2}{*}{$\begin{array}{l}\text { Months, } \\
\text { year }\end{array}$} & \multirow[b]{2}{*}{$\begin{array}{c}\text { Hours of } \\
\text { observations }\end{array}$} & \multirow[b]{2}{*}{$\begin{array}{c}\text { Total no. } \\
\text { of } \\
\text { animals } \\
\text { observed }\end{array}$} & \multicolumn{4}{|c|}{$\%$ of roe deer observed } \\
\hline & & & $\begin{array}{l}\text { Arable } \\
\text { lands }\end{array}$ & $\begin{array}{c}\text { Young } \\
\text { forest } \\
\text { plantations }\end{array}$ & $\begin{array}{l}\text { Ground } \\
\text { cover } \\
\text { in stands }\end{array}$ & $\begin{array}{c}\text { Ground } \\
\text { cover } \\
\text { under } \\
\text { oaks }\end{array}$ \\
\hline III. 1976 & 22 & 63 & 34.9 & 14.3 & 23.8 & 27.0 \\
\hline IV, 1976 & 24 & 61 & 34.4 & 41.0 & 24.6 & \\
\hline V, 1976 & 24 & 60 & 20.0 & 45.0 & 35.0 & \\
\hline VI, 1976 & 23 & 57 & 15.8 & 47.4 & 36.8 & \\
\hline VII, 1976 & 28 & 75 & 28.0 & 37.3 & 34.7 & \\
\hline VIII, 1976 & 31 & 108 & 16.7 & 44.4 & 38.9 & \\
\hline IX, 1976 & 23 & 78 & 12.8 & 50.0 & 37.2 & \\
\hline $\mathrm{X}, 1976$ & 23 & 93 & 6.5 & 51.6 & 10.7 & 31.2 \\
\hline $\mathrm{XI}, 1976$ & 28 & 90 & 3.3 & 40.0 & 13.3 & 43.4 \\
\hline XII, 1976 & 32 & 82 & 3.7 & 29.3 & 8.5 & 58.5 \\
\hline I, 1977 & 29 & 81 & 7.4 & 25.9 & 11.1 & 55.6 \\
\hline II, 1977 & 33 & 90 & 11.1 & 20.0 & 12.2 & 56.7 \\
\hline Total, Avg. & 320 & 938 & 15.0 & 37.3 & 23.3 & 24.4 \\
\hline
\end{tabular}

Table 5

The comparison of the utilization of the feeding areas types by the roe deer $(\%)$ in spring and autumn.

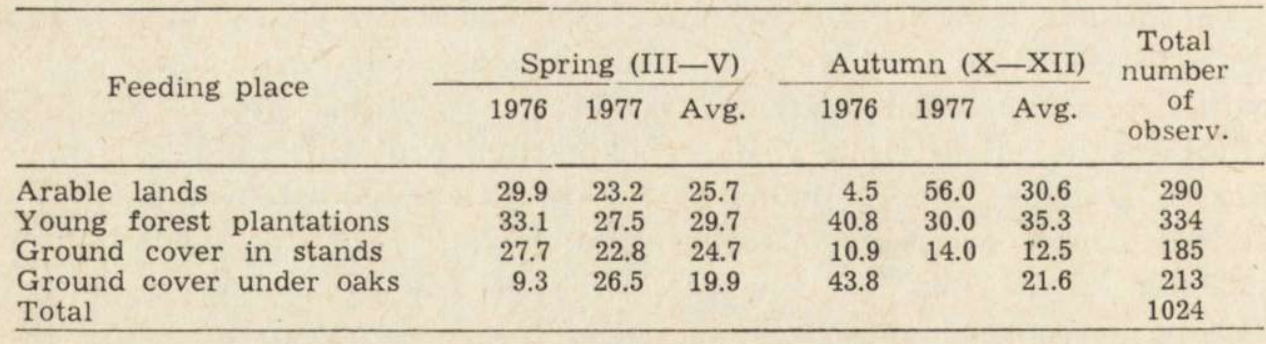

depends on good seed years (abundance of acorns, e.g. in 1976). On an average over the yearly cycle $(37.3 \%)$ and in both seasons of the year $(35 \%)$, plantations are most often used as feeding places (Tables 4,5$)$.

\subsection{Size of Bucks' Territories}

The average size of a buck's territory during the period from MarchSeptember, depending on the method accepted for mapping results of 
field observations, was: 9 ha in the case of the minimum polygon and 10.3 ha for the convex polygon. With Jenrich and Turner's method (1969), the area of probable activity was on an average 52.3 ha. Data, as yet unfortunately scanty, do not permit of defining correlations

Table 6

Territories (males) and home ranges (females) sizes estimation.

\begin{tabular}{|c|c|c|c|c|c|c|c|c|}
\hline \multirow{2}{*}{$\begin{array}{l}\text { No. of } \\
\text { deer }\end{array}$} & \multirow{2}{*}{$\begin{array}{l}\text { f Age, } \\
\text { approx. }\end{array}$} & \multirow{2}{*}{$\begin{array}{l}\text { Date and place } \\
\text { of marking }\end{array}$} & \multicolumn{3}{|c|}{ Observations } & \multicolumn{3}{|c|}{ Area size, ha } \\
\hline & & & No. & Year & Period & A & B & C \\
\hline & Males & & & & & & & \\
\hline 13 & & 29.II.1976, 159g & 15 & $\begin{array}{l}1976 \\
1977\end{array}$ & $\begin{array}{l}\text { 4.VII. }-15 . \mathrm{IX} \\
\text { 5.V.-26.VII }\end{array}$ & 8.7 & 10.6 & 30.0 \\
\hline 30 & $5-6$ & 8.III.1975, 161a & 5 & 1976 & 29.III.-18.VIII & 8.4 & 11.6 & 24.4 \\
\hline A 24 & $5-6$ & 5.III.1972, 159f & 10 & 1973 & 3.III.-21.VIII & 8.4 & 11.6 & 34.0 \\
\hline 10 & $2-3$ & 6.III.1976, 1401 & 8 & 1976 & 21.V.-20.X & 5.5 & 7.9 & 34.7 \\
\hline B15 & $4-5$ & 4.III.1973, 159a & 11 & $\begin{array}{l}1974 \\
1976\end{array}$ & $\begin{array}{l}\text { 4.VI.-19.IX } \\
\text { 18.V. }-30 . \mathrm{X}\end{array}$ & 6.4 & 6.4 & 35.5 \\
\hline 19 & $2-3$ & 16.II.1975, 137d & 6 & 1976 & 24.II--8.IX & 6.3 & 7.5 & 38.0 \\
\hline $\mathrm{BO} 4$ & $4-5$ & 11.III.1973, 163a & 6 & 1974 & 8.VI.-23.VIII & 8.6 & 9.2 & 50.0 \\
\hline $\mathrm{A} 23$ & 2 & 26.II.1972, $160 \mathrm{c}$ & 6 & 1974 & 4.IV.-28.VIII & 9.3 & 10.7 & 61.3 \\
\hline O7 & 2 & 6.III.1976, 96a & 5 & 1976 & 7.IV. $-27 . \mathrm{X}$ & 9.8 & 9.8 & 67.7 \\
\hline 20 & $2-3$ & 6.III.1976, $96 \mathrm{f}$ & 8 & $\begin{array}{l}1976 \\
1977\end{array}$ & $\begin{array}{l}\text { 4.VII.-28.VIII } \\
\text { 5.III.-4.VII }\end{array}$ & 15.5 & 16.4 & 71.5 \\
\hline 21 & 2 & 20.II.1976, 159g & 5 & 1977 & 3.IV -10. VIII & 11.3 & 11.3 & 80.5 \\
\hline 14 & $4-5$ & 16.II.1976, 137d & 6 & 1976 & 28.II.-25.IX & 13.5 & 17.1 & 100.6 \\
\hline Avg. & & & & & & 9.0 & 10.3 & \\
\hline & Females & & & & & & & \\
\hline B17 & $3-4$ & 6.III.1977, 159g & 7 & 1977 & 21.IV.-9.IX & 3.3 & 3.3 & 16.1 \\
\hline BO6 & $2-3$ & 25.II.1973, 137a & 8 & 1976 & 22.II.-12.IX & 5.9 & 6.8 & 28.4 \\
\hline 28 & $6-7$ & 8.III.1975, 95a & 8 & 1976 & 13.III.-22.XI & 3.2 & 4.8 & 34.0 \\
\hline 33 & $1-2$ & 11.III.1978, 137d & 5 & 1979 & 8.VII.-10.IX & 5.5 & 6.0 & 44.0 \\
\hline $\mathrm{A} 13$ & $2-3$ & 11.III.1978, 118a & 6 & 1973 & 9.IV.-8.VIII & 7.9 & 8.5 & 49.8 \\
\hline $\mathrm{O} 4$ & 1 & 4.II.1974, 26a & 5 & $\begin{array}{l}1979 \\
1980\end{array}$ & $\begin{array}{l}\text { 15.V.-17.VII } \\
28 . \mathrm{IV} .-4 . \mathrm{VII}\end{array}$ & 6.6 & 6.6 & \\
\hline BO8 & $4-5$ & 10.III.1973, 159g & 5 & 1974 & $25 . \mathrm{V} .-15 . \mathrm{VIII}$ & 4.6 & 4.6 & 52.5 \\
\hline A29 & $4-5$ & 22.II.1974, $137 \mathrm{~d}$ & 9 & $\begin{array}{l}1976 \\
1977\end{array}$ & $\begin{array}{l}\text { 6.V.-16.XII } \\
\text { 20.III.-23.VII }\end{array}$ & 16.7 & 20.4 & \\
\hline BO5 & 2 & 4.III.1973, 160b & 5 & 1973 & 16.VI.24.IX & 9.5 & 12.4 & 100.5 \\
\hline 17 & $3-4$ & 6.III.1976, 96a & 9 & 1977 & 15.V.-16.X & 19.5 & 26.2 & 112. \\
\hline $\mathrm{BO} 3$ & $3-4$ & 3.III.1973，26a & 5 & 1973 & 23.VI.-28.XII & 12.1 & 18.0 & 117.4 \\
\hline 22 & $6-7$ & 8.III.1975, $95 \mathrm{a}$ & 11 & $\begin{array}{l}1976 \\
1977\end{array}$ & $\begin{array}{l}\text { 20.VII.-18.XII } \\
\text { 7.II.-17.VII }\end{array}$ & 51.3 & 64.6 & 237.0 \\
\hline Avg. & & & & & & 12.2 & 15.2 & 77.0 \\
\hline
\end{tabular}

A - minimum polygon, B - convex polygon, $C_{-}-$elliptic area of probable activity.

between the size of territories and population density in different years (Table 6).

\subsection{Size of the Home Ranges of Does}

The existence of does' home ranges, despite the absence of manifestations of territorial behaviour, is not open to doubt. Calculation made for 12 females of the average size of the home range showed that this 
is more extensive than the territory of bucks, depending on the calculation method used, was 12.2 ha or 15.2 ha, but as much as 77 ha in the case of theoretically calculated area of probable activity (Table 6).

\subsection{Movements of Individuals in the Population}

The movements of individuals in a population are not usually over any great distance, and the territorial distribution of the population pointed to distinct stability.

A greater degree of settled residence is exhibited by males. Almost half of the individually marked bucks $(47 \%)$ were observed within a radius of up to $0.5 \mathrm{~km}$ from the place of their capture (Table 7). $84 \%$ of all bucks observed were found at a maximum distance of up to $1 \mathrm{~km}$ from their place of capture and marking. Only a small number of individuals had moved further away. The maximum distance from the place of capture $(2.3 \mathrm{~km})$ was found for buck 09, marked when a fawn.

Movements of does were far more often observed and in this case also, however, $54 \%$ of the does were observed at distances of up to $1 \mathrm{~km}$ from the place of capture, $33 \%$ of which at distances up to $0.5 \mathrm{~km}$. In extreme cases the distance over which they moved exceeded even $5 \mathrm{~km}$ in a straight line (Table 7). The animal marked B29 caught 27.2.1977, moved in the year following marking to a distance of about $5 \mathrm{~km}$ and ended its movement there. This doe was observed, together with its progeny, within an area not greater than about 15 ha (the number of observations being smaller than the number envisaged by the method made statistical calculation impossible) in successive years: 1978 (3.05), 1979 (27.1, 28.8), 1980 (10.5) and 1981 (10.8). In the case of other does also tendency to movements to greater distances occurred in individuals marked while still fawns (24, B11, B.14) or in individuals $1-2$ years old (B29, B19).

\section{DISCUSSION}

Population density exhibits annual fluctuations connected with effective increase and natural mortality, and shooting. When pressure from shooting is moderate and relatively stable, the spring, that is, prereproduction population density is shaped chiefly by means of natural losses occurring primarily during the winter period. Natural mortality, usually not great, causes losses of $33-35 \%$ - of the autumn population numbers (Fruziński \& Łabudzki, 1982) during frosty and snowy winters, and in consequence a decrease in spring population density (Fig. 1). 
Table 7

Local movements of individuals.

\begin{tabular}{|c|c|c|c|c|}
\hline \multirow[b]{2}{*}{$\begin{array}{l}\text { No. of } \\
\text { deer }\end{array}$} & \multirow[b]{2}{*}{$\begin{array}{c}\text { Date and place } \\
\text { marking }\end{array}$} & \multicolumn{3}{|c|}{ Observations } \\
\hline & & $\begin{array}{l}\text { Nearest } \\
\mathrm{km}\end{array}$ & $\begin{array}{c}\text { Farthest } \\
\mathrm{km}\end{array}$ & $\begin{array}{l}\% \text { of animals } \\
\text { observed in } \\
\text { a distance } \\
\text { (from-to, } \mathrm{km} \text { ) }\end{array}$ \\
\hline & Males & & & \\
\hline $\mathrm{B} 21$ & 7.III.1976, 95a & 0.1 & 0.3 & \\
\hline $\mathrm{B} 25$ & 7.III.1976, 118a & & 0.3 & $0-0.5 \mathrm{~km}$ \\
\hline 21 & 29.II.1976, $159 \mathrm{~g}$ & 0.2 & 0.3 & $47 \%$ \\
\hline O7 & 6.III.1976, 96a & 0.1 & 0.3 & \\
\hline $\mathrm{BO} 4$ & 11.III.1973, 163a & 0.1 & 0.4 & \\
\hline B15 & 4.III.1973, 159a & 0.1 & 0.4 & \\
\hline 19 & 16.II.1976, $137 d$ & 0.2 & 0.4 & \\
\hline 29 & 8.III.1975, $118 \mathrm{a}$ & 0.2 & 0.4 & \\
\hline B34 & 27.II.1977, $96 \mathrm{a}$ & 0.1 & 0.5 & \\
\hline 14 & 16.II.1976, $137 \mathrm{~d}$ & 0.2 & 0.6 & \\
\hline 20 & 6.III.1976, 96f & 0.2 & 0.6 & $0.6-1 \mathrm{~km}$ \\
\hline-30 & 29.II.1976, $159 \mathrm{~g}$ & 0.1 & 0.7 & $37 \%$ \\
\hline 47 & 26.II.1978, 119a & 0.5 & 0.7 & \\
\hline A24 & 5.III.1972, $159 f$ & 0.1 & 0.1 & \\
\hline A23 & 26.II.1972, $160 \mathrm{c}$ & 0.3 & 0.8 & \\
\hline 23 & 7.III.1976, 118d & 0.8 & 1.0 & \\
\hline 13 & 8.III.1975, $161 \mathrm{f}$ & 0.9 & 1.3 & above $1 \mathrm{~km}$ \\
\hline 10 & 6.III.1976, 1401 & 1.1 & 1.6 & $16 \%$ \\
\hline 09 & $\begin{array}{c}\text { 16.II.1976, 137d } \\
\text { Females }\end{array}$ & & 2.3 & \\
\hline B17 & 6.III.1977, 159g & 0.1 & 0.2 & \\
\hline A25 & 4.III.1972, $157 \mathrm{~b}$ & & 0.2 & $0-0.5 \mathrm{~km}$ \\
\hline 12 & 6.III.1976, $96 a$ & 0.1 & 0.3 & $33 \%$ \\
\hline A20 & 27.II.1972, $163 \mathrm{a}$ & 0.2 & 0.4 & \\
\hline $\mathrm{BO} 8$ & 10.III.1973, 159a & 0.1 & 0.4 & \\
\hline 33 & 11.III.1978, $137 \mathrm{~b}$ & 0.1 & 0.5 & \\
\hline 04 & 4.II.1974, $26 \mathrm{a}$ & 0.1 & 0.5 & \\
\hline 17 & 6.III.1976, 96a & 0.1 & 0.6 & $0.6-1 \mathrm{~km}$ \\
\hline BO5 & 4.III.1973, $160 \mathrm{~b}$ & 0.4 & 0.6 & $21 \%$ \\
\hline A29 & 22.II.1974, $137 \mathrm{~d}$ & 0.1 & 0.6 & \\
\hline 17 & 6.III.1976, $96 \mathrm{f}$ & 0.2 & 0.6 & \\
\hline $\mathrm{BO} 3$ & 3.III.1973, 26a & 0.3 & 0.8 & \\
\hline B26 & 6.III.1976, $96 \mathrm{a}$ & 0.1 & 1.1 & $1.1-2.0 \mathrm{~km}$ \\
\hline 22 & 8.III.1975, $95 a$ & 0.3 & 1.3 & $8 \%$ \\
\hline 28 & 8.III.1975, 95a & 1.2 & 2.1 & $2.1-3.0 \mathrm{~km}$ \\
\hline B11 & 2.II.1974, $137 \mathrm{a}$ & 0.2 & 2.2 & $21 \%$ \\
\hline A13 & 11.III.1972, 118a & & 2.3 & \\
\hline $\mathrm{A} 12$ & 27.II.1972, $163 \mathrm{a}$ & & 2.5 & \\
\hline 24 & 29.II.1976, 159g & 1.8 & 2.6 & \\
\hline BO9 & 24.II.1973, $118 \mathrm{a}$ & & 3.4 & above $3.1 \mathrm{~km}$ \\
\hline B19 & 27.II.1977, $96 \mathrm{a}$ & 0.2 & 4.8 & $17 \%$ \\
\hline B14 & 4.III.1973, $159 \mathrm{~b}$ & & 4.1 & \\
\hline B29 & 27.II.1977, $96 \mathrm{~b}$ & 0.3 & 5.2 & \\
\hline
\end{tabular}

Population density is also conditioned by the habitat situation and to a certain extent by geographical situation. In Poland population density of roe deer in large stretches of wooded land is from about 2 individuals per 100 ha (in certain parts of the Białowieża Primeval Forest and Augustów Forest) to 15 individuals (Pucek et al., 1975). 
Average population density at Zielonka (15.1 individuals/100 ha) is thus maintained on a high level despite shooting, which annually accounts for about $17 \%$ of the spring numbers. Fairly numerous data on the density of roe deer in some European countries, e.g. in the German Democratic Republic - 2.5/100 ha (Stubbe \& Passarge, 1979), German Federal Republic - 18 individuals/100 ha (Nüsslein, 1968), Czechoslovakia (Slovakia) about 4 individuals $/ 100$ ha (Hell, 1979) etc. have no comparative value, as they refer to total areas and not to given stretches of forest. The accurate data given by Strandgaard (1972), on the other hand, describe very small habitats. Even without the limits of one stretch of wooded land the population density of roe deer varied depending on biotopes, i.e. chiefly the species composition of the tree stand and its age structure.

In the majority of forests in Poland the density of roe deer is slightly higher in tree stands in which deciduous species predominate (Pucek et al., 1975). At Zielonka, over an 8-year period, the average spring population density is higher in coniferous forests in which pine predominates in the species composition of the tree stand. Although the difference is only slight, it is statistically significant (Table 2), and it is certainly the better feeding conditions which account for this.

Distinct and statistically significant differences in the density of roe deer in different development stages of tree stands are undoubtedly due to the different shelter conditions. The decidedly maximum population density in older plantations and thickets shows clearly how important suitable shelter is, since this ensures safe living and feeding over the daily cycle. In by far the majority of forests in other parts of Poland density of roe deer was highest when the proportion of plantation in the age structure of treestands was maximum, $10.3-11.7 \%$ (Pucek et al., 1975).

The degree to which roe deer use different parts of the forest biotope as feeding grounds varies seasonally, depending on the amount and accessibility of food. In small shelterbelts at Kalø roe deer made most intensive use of forest feeding places during the period from December-January and April-June (Strandgaard, 1972), whereas feeding in cultivated fields depended on the localization and structure of crops. The greatest attraction as a feeding place over the yearly cycle of forest plantations and herb layer under treestands at Zielonka is certainly due to some degree of stability in the food supply. Forest plantations continued to be attractive feeding places in the respective months on a similar level in different years (Table 5). Utilization of feeding places is thus an important, but clearly, varying, element of the population's spatial structure. 
Territorial systems have a definitely seasonal aspect. The size of bucks' territories and does' home ranges depends on a large number of factors, such as the value of the biotope from the aspect of feeding place and shelter, climatic conditions and population density (Hell, 1979; Stubbe \& Passarge, 1979). Many difficulties as regards method also arise as to correct definition of the size of territories and home ranges. Henning (1962) defines the size of territories of bucks 2 years old and older, as 8-12 ha, with very high population density (34 individuals/ $100 \mathrm{ha})$. In southern England the size of territories was about 10 ha, and in small woods 7.1-7.4 ha (Prior, 1968), in Denmark under similar conditions, 26-30 ha (Strandgaard, 1972). With population density similar to that found at Zielonka Kurt (1968) gives territory size for Switzerland as up to about 28 ha (with density of 20 individuals per $100 \mathrm{ha})$ and Mottl (1962) - 10.2-25.4 ha, depending on the season of the year (with density of 16 individuals per $100 \mathrm{ha}$ ). The majority of these data on European populations of roe deer do not, however, give exact details of the methods used for calculating territory size, and thus it is difficult to compare data. If we take as a basis territory size calculated by the convex polygon method ( $10.3 \mathrm{ha})$, in many cases these are nearly similar values. In view of the fact that the suitability of different methods for calculating territory size and shape is still open to discussion, with simultaneous constantly small numbers of field observations, we have given exact values for territories without attempting to give more detailed justification or recommendation of the given method used to calculate same. The method of defining the area of activity of elliptical shape would appear in particular to be debatable (Jenrich \& Turner, 1969).

Many authors have drawn attention to the relation between territory and age of the given individual, but only Nikolandic (1968) gives definite data, according to which 2-year old bucks have the most extensive territories ( $77 \mathrm{ha})$ and adult individuals the smallest ( $45 \mathrm{ha})$. The scanty material does not permit of definite confirmation of this phenomenon, although data analyzed (Table 6) would appear to show that adult bucks do $\mathrm{n}$ fact have the smallest territories. Field observations have, however, shown that the boundaries of these territories are very actively defended by the owner and respected by its neighbours.

The size of the home ranges of does also depends on the season of the year. The absence of active protection of the boundaries of such ranges probably makes it possible for them to live in a larger space than is the case with bucks. According to Kurt (1968), the average size of a home range in the lowland regions of Switzerland is about 49 ha (from 3 to $180 \mathrm{ha}$ ). Strandgaard (1972) also states quite clearly that the 
size of the home range of a doe is far larger than the territory of bucks, since the home range is often common to a large number of does.

At Zielonka the average size of the home range, depending on the method used for its calculation, was: 12.2 ha (3.2 ha larger than the territory of bucks) or 15.2 ha (difference 4.9 ha) (Table 6). There is some degree of contradiction here with Mottl's data (1962), who gives the size of the home range of does as $10-22$ ha and with Nikolandie (1968), who gives the average home range size for the roe deer as 37 ha (from 20 to $96 \mathrm{ha}$ ). This author and Kurt (1968) consider that it is the young 2-year does which have the largest home range. Some data from Zielonka also point to the existence of this regularity, since the largest home range was found for hinds $17 \mathrm{BO}$ and 22, marked when $2-3$ years old.

The size and range of movements undoubtedly form an important element of the spatial structure of the population. They certainly depend not only on population density, but also on the character of the habitat. They occur most intensively in overcrowded populations not used for hunting purposes, particularly if the population lives in small shelterbelts, round which intensive shooting takes place (Strandgaard, 1972). Mottl (1957), Raesfeld (1960), Rieck (1955, 1970), Myrberget (1973) and Blankenborn (1957) also indicate the important role played by movements for interchange of individuals and variations in population numbers.

Under the conditions at Zielonka, which is a large stretch of forest to some extent isolated from other such stretches, the range of movement is limited in comparison with data given by the authors referred to above. In our case also the furthest movements occurred in the case of young individuals, marked at the age of $8-10$ months. Movements took place in spring, soon after marking, which is certainly connected with the search for territory or home range, although the presence of the youngest bucks is often tolerated by the owner of the territory, depending on their condition and behaviour (Strandgaard, 1972). More limited movement of males may be connected with their territorial behaviour in spring and summer. There are as far on data available on observations of marked individuals outside the Zielonka stretch of forest, although the lack of information cannot be taken solely to mean that no further movements took place at all.

Acknowledgements: Field work was carried out with considerable assistance from members of the Forestry Students Scientific Circle of the Academy of Agriculture in Poznań. The authors are also grateful to M. Franczak, M. Sc and K. Eagodziński for their contribution to the collection of study material. 


\section{REFERENCES}

1. Blankenborn H. J., 1975: Kitz-Markierungs Aktion, 1970-1971. Jäger. 9: $42-45$.

2. Fruziński B. \& Eabudzki L., 1982: Demographic processes in the forest roe deer population. Acta theriol., 27: 365-376.

3. Fruziński B. \& Eabudzki L., 1982: Sex and age structure of the forest roe deer population under pressure of shooting. Acta theriol., 27: 377-384.

4. Hell P., 1979: Srncia zver. Priroda: 1-310. Bratislava.

5. Hennig R., 1962: Ủber das Revierverhalten der Rehböcke. Z. Jagdwiss., 8: $61-81$.

6. Jenrich R. \& Turner F. B., 1969: Measurement of non-circular home range. J. thereot. Biol., 22: 227-237.

7. Kurt F., 1968: Das Sozialverhalten des Rehwildes. Mammalia Depicta, 4: 1-102. Hamburg-Berlin.

8. Mottl S., 1957: Die Jagdwirtschaflich erforderliche Mindestgrösse Rehwildrevieren im Walde. Z. Jagdwiss., 3: 64-69.

9. Mottl S., 1962: Zur Frage der Wilddichte und der Qualität des Rehwildes. Beitr. Jagd-u. Wildforsch., 2: $34-40$.

10. Mucha W. \& Margowski Z., 1957: Operat glebowy Nadleśnictwa Doświadczalnego Zielonka. Kat. gleb. WSR Poznań.

11. Myrberget S., 1973: Marking av radyr in Norge. Fauna, 2: 97-101.

12. Nikolandie D., 1968: Ókologische Charakteristik der Rehpopulation im Distrikt Belje. Jelen, 7: 73-95, Beograd.

13. Nowaczyk Cz., 1964: Zespoły leśne doświadczalnego nadleśnictwa Zielonka pod Poznaniem. Poznań. Tow. Przyj. Nauk, Wydz. Nauk. Rol. i Leśn. 17: 214-271.

14. Nüsslein F., 1968: Die Entwicklung der Wildbestände in der Deutschen Bundesrepublik von 1956 bis 1965 . Beitr. Jagd-u. Wildforsch., 6: 17-26.

15. Pielowski Z., 1970: Sarna. Państw. Wyd. Roln. i Leśn.: 1-210. Warszawa.

16. Prior R., 1968: The roe deer of Cranborne Chase. An ecological survey. Univ. Press.: 1-119, Oxford, London.

17. Pucek Z., Bobek B., Łabudzki L., Miłkowski L., Morow K. \& Tomek A., 1975: Estimates of density and number of ungulates. Polish ecol. Stud., 1: 121-135.

18. Raesfeld F., 1960: Das Rehwild. Parey: 1-328. Hamburg-Berlin.

19. Rieck W., 1955: Die Setzzeit bei Reh- Rot- und Damwild in Mitteleuropa. Z. Jagdwiss., 1 : $69-75$.

20. Rieck W., 1970: Alter und Gebissabnutzung beim Rehwild. Eine Auswertung der Wildmarkenforschung. Z. Jagdwiss., 16: 1-6.

21. Southwood T. R. E., 1966: Ecological methods. Methuen \& Co. London.

22. Stickel L., 1954: A comparison of certain methods of measuring ranges of small mammals. J. Mamm., 35: 1-15.

23. Strandgaard H., 1972: The roe deer (Capreolus capreolus) population at Kalø and the factors regulating its size. Danish Rev. Game Biol., 7: 1-205.

24. Stubbe Ch. \& Passarge H., 1979: Rehwild. VEB Deutscher Landwirtschaftsverlag: $1-431$, Berlin.

Accepted, March 21, 1983, 


\section{Bogusław FRUZIŃSKI, Lesław ŁABUDZKI i Marian WLAZEŁKO

\author{
BIOTOP, ZAGĘSZCENIE I STRUKTURA PRZESTRZENNA \\ POPULACJI SARNY LESNEJ
}

Streszczenie

Na podstawie badań przeprowadzonych w latach 1973-1980 w Łowieckim Ośrodku Doświadczalnym „Zielonka” (około 8000 ha powierzchni leśnej) określano zagęszczenie i organizację przestrzenną populacji sarny. Charakter biotopu wymagal zastosowania różnych metod badawczych, jak pędzenia próbne, transekt liniowy, czy wreszcie bezpośrednia obserwacja znakowanych indywidualnie osobników.

Stwierdzono zmienność zagęszczenia populacji od 20,8 osobnika na 100 ha do 10,4/100 ha (Ryc. 1). Najważniejszą przyczyną wahań liczebności były warunki atmosferyczne okresu zimowego. Wyższe zagęszczenie populacji (16,1 osobnika/100 ha) stwierdzono $\mathrm{w}$ drzewostanach o przewadze sosny w składzie gatunkowym, niż w drzewostanach liściastych i mieszanych o przewadze dębu (14,1 osobnika) (Tabela 2). Wyraźne, istotne pod względem statystycznym, różnice zagęszczenia populacji saren stwierdzono $w$ poszczególnych stadiach rozwojowych drzewostanów. Zdecydowanie najwyższe zagęszczenie populacji w starszych uprawach $(21,7$ osobnika) i młodnikach (20,9 osobnika) (Tabela 3) świadczy o dużym znaczeniu warunków osłonowych.

Wykorzystanie przez sarny poszczególnych fragmentów biotopu jako żerowisk jest istotnym, lecz wyraźnie zmiennym elementem struktury przestrzennej populacji. Jedynie atrakcyjność upraw leśnych i runa w drzewostanach jako żerowisk utrzymuje się na zbliżonym poziomie w cyklu rocznym (średnio odpowiednio $37,3 \%$ i $23,3 \%$ obserwacji) w różnych latach, co świadczy o znacznej stabilności tego elementu bazy żerowej. W latach nasiennych dębu żołędzie stanowią podstawowy składnik żeru sarn aż do wiosny (w listopadzie $58,5 \%$ obserwacji) (Tabele 4 i 5 ).

Srednia wielkość terytorium kozłów, w zależności od zastosowanej metody kalkulacji wyniosła: 9 ha $w$ przypadku wieloboku minimalnego (minimum polygon), 10,3 ha przy wieloboku wypukłym (convex polygon) i 52,3 ha w przypadku obszaru prawdopodobnej aktywności w kształcie elipsy (Tabela 6).

Srednia wielkość areałów osobniczych kóz wyniosła odpowiednio 12,2 ha, 15,2 ha oraz 77 ha (Tabela 7 ).

Układ terytorialny populacji nosi cechy wyraźnej stabilności, przy czym wyższy stopień osiadłości wykazały osobniki męskie: $84 \%$ wszystkich oznakowanych kozłów obserwowano w odległości do $1 \mathrm{~km}$ od miejsca odłowu, w tym aż $47 \%$ w promieniu do $0,5 \mathrm{~km}$ (Tabela 8). W przypadku kóz odpowiednio $54 \%$ i $33 \%$ (Tabela 9). Migracje na najdalsze odległości $(2,3 \mathrm{~km}$ u kozłów i $5,2 \mathrm{~km}$ u kóz) podejmowały osobniki, najmłodsze, odłowione i oznakowane jako koźlęta. 